\title{
Reviewing Specific Oversights in Civil Litigation Reforms in Malaysia
}

\author{
Norman Zakiyya, $\mathrm{b}^{*}$ \\ Kamal Halili Hassanc \\ aFaculty of Law, National University Malaysia, 43600, UKM Bangi, Selangor, Malaysia \\ bSenior Lecturer, Faculty of Syariah and Law, Universiti Sains Islam Malaysia, Bandar Baru Nilai \\ 71800 Nilai, Negeri Sembilan, Malaysia \\ c Professor, Faculty of Law, National University Malaysia, 43600, UKM Bangi, Selangor, Malaysia \\ ${ }^{*}$ Corresponding author: zakiyy@usim.edu.my
}

\section{Doi:10.5901/mjss.2015.v6n6p428}

\section{Abstract}

Judicial reforms in the administration of justice system generally affect the landscape of civil litigation. However, judicial reforms also draw adverse inference on the justice system if certain safeguards are lacking behind or delicate issues of public importance are not emphasized. This study aims at analysing he Malaysian Judiciary Reforms to civil litigation in Malaysia. The method of analysis is based on content analysis. This study indicates that the key catalyst to the success of civil litigation reforms of the Malaysian Judiciary (2008-2011) was contributed by excellent leadership. The study also finds that the Judicial Reforms in relation to management carry qualities that are recognized under established management practices. Nevertheless, the findings also show that there are crucial matters that are not contemplated in the said reform exercise such as the creation of a multi-door courthouse programme, methods to resolve complex civil cases and the plight of unrepresented litigants. Therefore, it is imperative for the Malaysian Judiciary to emphasize on these oversights in its future reform exercise.

Keywords: Court reforms, civil litigation, Malaysia

\section{Introduction}

Generally, judicial reforms are essential to restore public confidence in the judiciary's ability to dispense justice by improving the quality of judicial service. Notably, the traditional English Civil Justice System underwent lengthy review. Historically, it was reported that there had been no less than 63 reports on issues regarding to the procedural laws prior to the establishment of the Civil Justice Review in 1985 (Darbyshire, 2001). Nowadays, disputants are more aware of their rights than previously. Thus, it is insufficient if the judiciary only commands respect from the government, but not the public (Suffian, 2000). In 2001, the Kuala Lumpur Bar Committee issued a memorandum containing resolutions pertaining to the administration of justice in Malaysia. The said memorandum stated the adverse comments from the public and international community on the administration of justice in Malaysia (Memorandum from the Kuala Lumpur Bar Committee, 2001). The memorandum also included several proposals for reform regarding issues involving the judicial role in mega suits, contempt of court cases, unusual court orders and contempt of court cases.

2011 was a turning point for the Malaysian Judiciary. The World Bank prepared a report titled "Court Backlog and Delay Reduction Programme: Malaysia Court Backlog and Reduction Program". The report disclosed that the Judicial Reforms were not only significant, but should be emulated by other jurisdictions (World Bank Report, 2011). No doubt, the public's confidence in the Malaysia Judiciary has increased as a result of the introduction of the Court Backlog and Delay Reduction Programme ("Judicial Reforms"). Nevertheless, any judicial reform needs to be reconsidered upon the expiry of a term. The World Bank Report made important remarks on important leadership in the Judicial Reforms. It also contained important suggestions for the inclusion of IT development programmes in the court's future reform programmes. Apart from that, it also suggested in-depth studies on issues pertaining to dispute resolution forums.

Apart from the World Bank Report, there are a few recent writings about the Judicial Reforms in Malaysia. The relevant scholarly works have discussed on the e-court system in Malaysia (MahWengKwai \& Associates, 2013; Saman and Haider, 2012) and management of e-court records (Johare et al, 2009). However, these literatures have not ventured into examining the suggested future studies that were mentioned in the World Bank Report. Thus, the main objective of this study is to examine the issues that exist as a result of the Judicial Reforms. The general objectives are to examine: (a) the catalysts behind the Judicial Reforms; (b) key issues in managing civil cases in the aftermath of the Judicial 
Reforms; and (c) whether the civil litigation management reforms carry quality values in the theoretical sense of management.

It is viewed that the findings of this study are significant because they might contribute to the cumulative understanding among court managers and the legal fraternity on the importance of including critical matters that are vital in court reform exercises. In this study, for example, the limited use of alternative dispute resolution mechanisms ought to be given emphasis in future judicial reforms. From the theoretical aspect, this study contributes to enriching the current literature on the subject of court reforms, procedures and management.

The following sections describe the issues surrounding the Judicial Reforms.

\section{Brief Development of Judicial Reforms in Malaysia}

\subsection{Historical Situations leading to Judicial Reforms}

In 2011, the World Bank released a report on the Malaysian Judiciary effort titled "Malaysia Court Backlog and Delay Reduction Programme" (World Bank Report, 2011). Based on the analysis of the World Bank Report (2011), circumstances leading to the Judicial Reforms are public awareness, inefficiency of the courts, poor court management.

\subsubsection{Public awareness}

The growth of public dissatisfaction against the Malaysian Judiciary began somewhere in the late 1980s. It was reported to be in a deteriorating state in terms of efficiency in the disposal of cases. No doubt, it eventually lost the public's confidence in it as the custodian of justice for the nation (World Bank Report, 2011). By way of comparison, Singapore experienced judicial reforms in 1990. At the material time, the emphasis of the Singapore Judiciary was on case management and pre-trial conferences (Jackson, 2013). Occasionally, filing staffs from legal firms experienced difficulties in filing cause papers when the name of an honorific title was stated incomplete or wrongly (World Bank Report, 2011).

\subsubsection{Inefficiency of the courts}

Each judge was reported as considering oneself as the master of his own chambers and court. He lived in a world of relative isolation. Cases were struck out based on technicalities. For instance, in Han Euu Tiam v Phang Kui Fatt [1999] 4 MLJ 684, the court struck out the affidavit because the jurat did not reproduce the exact descriptive words stated in statutory form. The internal management of the court was left almost to his own decision. Files were found to be in a disorderly manner during the visit by Tun Zaki (the former Chief Justice of the Federal Court of Malaysia) in 2008 (World Bank, 2011). Tun Zaki found support from his team of reformers consisting of senior court judges. The team found that the courts were also troubled by inefficiencies due to shortage in manpower and proper documentation (Saman \& Haider, 2012). The deteriorating situation of the courts prompted Tun Zaki to act wittingly.

\subsubsection{Poor court management}

Between 2002 and 2005, a group of senior judges attempted to revamp the poor state of affairs of the judiciary. They were eager to do so upon sharing experiences with judges from other jurisdictions about the state-of-art in automated court system (World Bank Report, 2011). In East Malaysia (Sabah and Sarawak), it was reported that a reputable firm was engaged to install an automated case management system. Awkwardly, the 'project' was abandoned. The World Bank also reported that there were attempts to improve the state of case disposal by the courts. This included the introduction of pre-trial case management in 2000. However, the impact of such introduction was too minimal.

\subsection{Key Changes in civil litigation management as a Result of the Judicial Reforms}

\subsubsection{Promotion of mediation}

Mediation was introduced as a form of alternative dispute resolution in the civil courts (Mah, 2012). Tun Zaki made an effort to promote its use as an effective alternative dispute resolution mechanism. Positive steps were made especially by the implementation of Practice Direction No 5 of 2010 on mediation. This was the first formal introduction of mediation into the mainstream by encouraging parties to settle their cases instead of having them litigated in trials. In 2011, several 
mediation centres were established in major cities in Malaysia. These cities are Kuala Lumpur, Kuantan and Johor Bharu. The success rate of mediated cases was commendable for a start. For example, the success rate for mediated cases is around 28.3\% in Kuala Lumpur (Arifin Zakaria, 2013).

\subsubsection{The introduction of electronic justice}

In order to optimise efficiency and effectiveness in managing civil cases, the dispensation of justice has been transformed tremendously. Electronic court system has been introduced. One of such system is Case Management System (CMS) which was introduced together with e-filing of court documents (Hassan \& Mokhtar, 2011). This enables cases to be tracked apart from scheduling trial dates. Other than CMS, Queue Management System (QMS) was introduced to ease daily 'human traffic' in the courts because it helps the court to manage cases which have been fixed for hearing for a particular day. This means that attending solicitors get to be connected to the court by using the kiosk to confirm their case number and be informed of the actual time for the calling of their case to be heard before the judge or judicial officer via short-messaging system (SMS) (World Bank, 2011).

Remarkably, the use of electronic services has increased tremendously after the Judicial Reforms. Figures obtained from the official website of the Office of the Chief Registrar of the Federal Court of Malaysia indicate that there is an increase in the use of online service transactions, namely e-complaints, e-complaints and enquiries, e-filing and webmail. As of November 2013, there were 313,457 e-flings in West Malaysia and 14,274 in Sabah and Sarawak. As of 2014, there were 402, 910 e-filings in West Malaysia, and 12,863 in Sabah and Sarawak. In 2014, there were 437 ecomplaints and enquiries. As of January 2015, there were only 6 e-complaints and enquiries. However, as of January 2015, there were 34,015 e-filings. These figures indicated that the Judicial Reforms that promotes the use of electronic court management with the emphasis of CMS and e-filing are at par with the court management in more developed jurisdictions. They also reflect that the compulsory use of e-service is in harmony with recent modern court management. For example, the Utah Courts' website, (http://www.utcourts.gov/efiling/) disclosed that eFiling is now made compulsory for attorneys in matters relating to civil, probate and domestic matters (See Utah Court of Judicature Act, Rule 4-503).

The aftermath of the Judicial Reforms pertaining to electronic court services also witnessed the interests of the Malaysian Judiciary to extend such services to auction sale of land. Notably, the Chief Justice of the Federal Court of Malaysia (The Right Honourable Tun Arifin Zakaria) has recently proposed 'e-biding' to protect genuine real property purchasers from the intervention of cartels in court auctions (The Star, Nation Column, p. 10, 30 September 2014). This laudable proposal is meant to prevent syndicate members from registering for a prospective property in demand, but later payoff genuine purchasers to withdraw from the auction sale.

\section{Method}

The methodology used in this study is qualitative. Primary data were collected mainly from case laws. Secondary data were obtained from various sources which include reports, books, journals, proceeding papers, and information retrieved manually and electronically (via Google Scholar). The approach used is comparative analysis, namely by making comparisons between domestic practices in Malaysia and foreign jurisdictions. All collected data were analysed using the content analysis method; consisting of descriptive, analytical and critical analysis. Such methodology was chosen because the nature of this study involved both the areas of law and management. Thus, an analysis of statutory provisions and case laws, in specific, was deemed appropriate to study the situational constraints that have contributed to the oversights in civil litigation reforms in Malaysia.

\section{Analysis of Findings and Discussion}

This study indicates the following findings:

4.1 Key catalysts that contributed to the success of the Judicial Reforms was due to the excellent leadership of the former Chief Justice of the Federal Court of Malaysia

Based on the analysis of the World Bank Report, 2011, it can be inferred that the key promoter to the Judicial Reforms was Tun Zaki who demonstrated excellent leadership in transforming the Malaysian Judiciary. The evidence shows that he attempted to address the public concern over the deteriorating state of the judiciary that could not be remedied by his predecessors. He did so by addressing the issues of inefficiency of the courts and poor court management by introducing 
key reforms. These reforms are such as the introduction of electronic courts, the division of tasks among judges in hearing trial matters and affidavit hearings, and the promotion of mediation.

Tun Zaki has demonstrated leadership quality by putting emphasis on the priority for reform. As posited by Bennis (1989), the difference between a leader and a manager is that the former gives priority on "doing the right thing, whereas the latter emphasizes on "doing things the right way". He had demonstrated competency in leading the Malaysian Judiciary as evidenced by the disposal of cases within strict timelines. His success definitely fit into the definition of competency - a "combination of knowledge, skills, behaviours and attitudes" (Hellriegel et. al., 2000).

4.2 Key issues that are not deliberated in the Judicial Reforms are relating to the overreliance on mediation, nonexistence of a multi-door courthouse programme, complex civil case management, the plight of unrepresented litigants and high costs of maintaining electronic services.

\subsubsection{The overreliance on mediation and non-existence of a multi-door courthouse programme}

There is concern among members of the legal fraternity that trial judges are involved in the mediation process. This raises the issue of conflict of interests or biases. Thus, it is suggested that a better way is to refer disputes to the Malaysian Mediation Centre under the auspices of the Malaysian Bar Council (Albert and Azzat, 2010). Another worrisome concern is whether the parties would be deemed as being ripped-off their liberty to have their cases decided before the court if they were to be directed by the court to refer their disputes to mediation for settlement discussion in accordance with Practice Direction No. 2010. Judicial direction based on such reason may not be appropriate. This is because some would prefer to have their cases litigated before a court of law in order to determine the 'end result' of their case based on the merits, rather than on a "win-win situation".

Unfortunately, the World Bank Report 2011 did not explain or make any deliberation on the rationale of promoting court-connected mediation on a large scale. In reality, there are identified pitfalls to mediation such as lack of authority to settle; ill-preparation for mediation; and hostility and emotional attack by each or both parties (Chandran, 1999). Apart from that mediation can be a high risk procedure if the mediator lacks the necessary skills (Sheppard, 1993) and in situation where the parties are 'coerced' into mediation, freedom to negotiate their disputes are deemed diminished (Zakiyy, 2010).

Realistically, there are many factors that need to be considered before the court should encourage or even direct the parties or their solicitors to refer their cases to mediation. According to Mohiuddin (2009:227), a dispute intensifies by stages and the intensity of a dispute depended largely on the level at which the dispute has been discovered. Thus, a particular technique must be employed based on the intensity of the conflict. Blake et. al (1968), on the other hand, emphasise on the importance of making assumption about disputes and the stakes towards its result. They explained that there are three kinds of assumption that can be made about a dispute, namely: (1) where conflict is inevitable, agreement is possible; (2) where conflict is not unavoidable, yet agreement not possible; and (3) despite there is conflict, agreement is possible. Thus, it is crucial for the courts to consider that in their court-annexed ADR programme, different circumstances would require different types of resolution methods.

The promotion of a multi-door courthouse programme is not new to many developed jurisdictions, such as in the United States, Australia and United Kingdom. At present, however, there is lack of desirability of the Malaysian Judiciary to introduce other types of ADR mechanisms as court-connected ADR. It is therefore necessary for the Malaysian Judiciary to refer to other jurisdictions that have had promoted a number of court-connected ADR mechanisms. For instance, the Victoria Law Reform Commission (VLRC) recommended the use of other forms of ADR mechanisms, namely: (a) early neutral evaluation; (b) case appraisal; (c) mini-trial/case presentation; (d) the appointment of special masters: (e) court-annexed arbitration; (f) greater use of special referees to assist the court in the determination of issues or proceedings; (g) conciliation; (h) conferencing, and (i) hybrid ADR processes (Victorian Law Reform Commission Civil Justice Review: Report, p. 219). Similarly, in the United States, the U.S. District Court for the Northern District of California introduces a number of ADR mechanisms such as mediation, early neutral evaluation, nonbinding arbitration, and settlement conferences. Civil Local Rule 16 for example, stipulates the following: "every attorney and client certifies that they have read the handbook entitled Dispute Resolution Procedures in the Northern District of California and considered the ADR options".

\subsubsection{Addressing Complex Cases}

Complex cases are part and parcel of civil litigation in any jurisdiction. Nevertheless, the Judiciary Reforms have not 
addressed the issue of managing complex cases in an efficient manner. There are a few issues that the Judiciary Reforms have not addressed in terms of complex cases. Firstly, there is no strict definition of complex cases either in the interpretation section under the Rules of Court 2012 or as suggested in reported case laws. Secondly, there is no specific procedure prescribed for resolving complex cases.

As posited by Malayalam (2005), non-contentious work only attracts a small legal fee. At present, Malaysian solicitors firms are not required to adhere to a particular scale for such type of work. What is required of them is to charge a reasonable and fair amount of legal fee. However, in contrast, it is generally perceive that solicitors need to conduct indepth study in handling complex cases. In this connection, Rule 11 of the Legal Profession (Practice \& Etiquette) Rules, 1978 stipulates that certain factors must be taken into consideration by a solicitor in representing a litigant. Key factors mentioned in the aforesaid rule are: (1) the time, labour and skills involved; (2) the novelty and difficulty of the matter; (3) the customary charges of the profession for similar type of service; (4) the amount in controversy; and (5) the special position or seniority of the particular solicitor representing the case. Based on the understanding of aforesaid rule, it is submitted that complex cases generally involve huge legal costs.

Recent case laws tend to indicate that the Malaysian courts have considered the importance of managing complex cases and the nature of their complexities. This is evident in a number of recently decided cases. In Positive Well Marketing Sdn. Bhd. v. OKA Concrete Industries Sdn. Bhd. [2013] 8 CLJ 1083, Ummi Kalthum Abdul Majid, J. remarked that the case before her ladyship was regarded as complex because "because it involved difficult question of law and required substantial and specialised knowledge and responsibility to conduct the case". Similarly, in Khairy Jamaluddin v. Dato' Seri Anwar Ibrahim [2013] 6CLJ 849, Anantham Kasinather, JCA, in delivering the judgment of the Court of Appeal the court inter alia held that "The issues of law stated here were not just issues which at the first blush appeared complex but were genuinely complex and required careful consideration by the High Court" (p.850). The cited cases indicate that extra care and attention must be given to the disposal of such cases.

It is noteworthy to ponder the words of Lord Woolf (1999a) who reminded that the approach to litigation reforms must be focused on "achieving greater simplicity, proportionality, expedition and reducing the issues and expense". In this connection, the Malaysian Judiciary in its Judicial Reforms demonstrated simplicity as evident by introducing only two modes (instead of four previously) of commencing civil cases for both high courts and lower courts - summons and notice of application. In terms of expedition, the introduction of numerous e-court systems and fixing strict timelines for case disposal are sufficient proofs that show attempts by the judiciary to expedite the resolution of civil cases. Nevertheless, it is arguable whether proportionality is demonstrated by the Malaysian Judiciary in the aftermath of the Judicial Reforms. In England, for example, proportionality is achieved by the court distributing fresh cases into different tracks according to complexity of claims. As mentioned by Lord Woolf (1999b), in England and Wales, multi tracks are specifically allocated for complex cases to enable close judicial monitoring and efficiency in case disposal. The allocation of complex cases is now stated under Rule 26.6 (6) Civil Procedure Rules 1998.

\subsubsection{Addressing plight of unrepresented litigants}

The Judicial Reforms have no doubt simplified the conduct of civil litigation for both the court and solicitors. But this is not necessarily true for the unrepresented litigants. Thus, the issue of simplification of court procedures in the aftermath of Judicial Reforms has not been put to rest, especially regarding the plight of unrepresented litigants.

The plight of the unrepresented litigant is an international problem. Thus, effective and concerted measures must be made to mitigate their problems. Nevertheless, the World Bank Report 2011 did not report any findings on the effort of the Malaysian Judiciary regarding this issue. In Australia, the importance of this issue (unrepresented litigants' plight) has been raised in the case of Queensland v J L Holdings Pty Ltd (1997) 189 CLR 146 [154] (per judgment of Dawson, Gaudron and McHugh JJ). The court is said to be overly complicated and the courts have mentioned about the inability of unrepresented litigants to manage their cases (Silver, 2013a). According to Silver (2013b), parties to an action become unrepresented litigants due to the following reasons: (a) jurisdiction; (b) financial constraints to engage legal representations; (c) refusal of lawyers to act; and (d) personal decision. In addition, it is opined that unrepresented litigants use plenty of judicial time and "require considerable patience and interpersonal skills from registry staff and judges" (Davies, 2003). At this juncture, it is vital to take note of the law reform that took place in England and Wales. According to Prest and Anlieu (2004), the Woolf's Final Report identified two key constraints to justice, namely court costs that are extremely high and legal fees.

In addition, an unrepresented litigant who has little knowledge of the law would face difficulties in understanding the various terminologies used when referring to costs under Order 59 of the Malaysia Rules of Court 2012. The terms stated in the Table mentioned under the said Order are as follows: "Costs"; (b)"Costs reserved", (c) "Costs in any event"; 
(d)"Costs here and below"; (e) Costs in the cause" or "Costs in the application"; (f)"Plaintiff's costs in the cause" or "Defendant's costs in the cause"; (g)"Costs thrown away"; and (h)"Costs paid forthwith".

As a consequence of facing difficulty in deciphering the actual meaning attached to such complicated terminologies, an unrepresented litigant (especially one who is not eligible for legal aid service) might find it difficult to form a correct judgment as to whether it is wise to proceed with the action or otherwise. Case laws show that the question of costs is one which is within the discretionary powers of the court (see for examples, the Court of Appeal in Hai Yue Hin v Public Feedmill (M) Sdn Bhd (1997) 4 AMR 3637 has referred to the former Rules of the High Court 1980, namely Order 59 rule 4(1) and decided that the question of costs is a matter which is left to the discretion of the court. Similar decision was decided in Petroleum National Berhad \& Anor. v. Cheah Kam Chiew (1987) 1 MLJ 50, where Hashim Yeop Sani SCJ inter alia observed that the court's discretionary power as to costs is spelt out in the Courts of Judicature Act 1964 section 68(1)(c). His lordship observed that: "If the court in the exercise of its discretion sees fit to make any order as to the costs of or incidental to any proceedings, the court shall, subject to this Order, order the costs to follow the event, except when it appears to the court that in the circumstances of the case some other order should be made as to the whole or any part of the costs."

\subsubsection{Efficient and cost saving use of electronic system must be within allocated budget}

It is important for the Malaysian Judiciary to strike a balance between overzealous interests to use electronic court system and allocated costs to maintain the same. Indeed, the road map for electronic justice is vague and ever changing through the passage of time.

In 2000, Singapore started to use the Electronic Filing System (EFS) in managing civil litigation. However, an enhanced E-Litigation EFS replaced the EFS which ceased operation in February 1, 2014. According to Newick (2014), the Hong Kong Judiciary found that the discovery of electronically stored information in civil litigation is costly and complex. Thus, Practice Direction SL1.2 was introduced on September 1, 2014 which provides rules for managing disclosure of electronically saved information (ESI) in the course of civil litigation proceedings.

\subsection{Court management reforms carry qualities that are recognized under established management practices}

There are evidences pointing to the transformation of an archaic civil court system to an advanced system which is dependable on the use of information technology. These evidences are in the implementation of the electronic court system (including CMS), the simplification of court rules for management of cases purpose and the introduction of pretrial case management. Efforts for such reforms are consistent with well-recognised management theories. According to Kotter (2001), management is related to coping with complex situations. In this relation, it is observed that the Malaysian Judiciary has overcome the early obstacles that it faced prior to the Judicial Reforms. For examples, the team of reformers found that the courts were disorganized and there were incidents of case backlog.

Under the competent leadership of Tun Zaki (the former Chief Justice of the Federal Court of Malaysia, the Malaysian Judiciary changed the landscape of civil litigation by employing effective management exercises such as the implementation of strict timelines for case disposal and electronic services. In this connection, these actions indicated competency in dealing with organizational management. As posited by several scholars in the field of management studies, competency is regarded as the key factor in determining the success of an organization (Lewis et al., 2004; Whetton \& Cameron, 2002; and Schermerhorn Jr, 2002). In this regard, Whetton and Cameron (2002) emphasise some of the key competencies from the viewpoint of management, which include managing the following matters: conflict; individual decisions; time and stress; motivating and influencing others; defining and solving problems; self-awareness; setting goals and articulating a vision. These competencies are demonstrated in the Judicial Reforms.

\section{Concluding Remarks}

The Judicial Reforms have brought positive change to how civil litigation is managed in Malaysia, especially in terms of using electronic services. However, it is important to chart the right course in the aftermath of the Judicial Reform. This is especially because the landscape of civil litigation is prone to change from time to time and so is the public's confidence in the Malaysian Judiciary.

Adverse comments against any judicial reforms would usually analyse the justification behind any of such reforms. Issues hampering the effort of the court to project its level of efficiency must be addressed without delay. For example, the absence of a special track or procedural rules to manage complex cases is untenable. Similarly, unrepresented 
litigants less benefit from the Judicial Reforms if they are not well acquainted with the rules especially regarding costs. In addition, they might delay the court's effort to dispose cases within specified timelines. In addition, the computerization of the courts on a large scale is a costly affair. This is because it involves the development of software and hardware. Thus, promoting e-justice is subject to limitation of public funds. It is unwise if the Malaysian Judiciary is to emulate the steps taken by developed countries without taking into consideration of her own state of affairs.

\section{Imitations and Future Studies}

The analysis of this study was based largely on information obtained from the World Bank Report 2011. Nevertheless, this study has only reviewed a number of specific issues pertaining to the Judicial Reforms. Thus, future studies should venture into examining other related issues that have not been discussed in this study or have not been contemplated in the Judicial Reforms.

\section{References}

Albert, D. and Azzat, F., MLC (2010). Latest Developments in Civil and Commercial Courts. [Online] Available: http://www.malaysianbar. org.my/bar_news/berita_badan_peguam/mlc_2010_latest_developments_in_civil_and_commercial_courts.html (October 2, 2014).

Bennis, W. (1989). Why Leaders Can't Lead, Training and Development Journal, 43, no.4.

Blake, R.R. et.al. (1968). Managing intergroup conflict in the industry. Houston: Gulf Publishing Co.

Chandran, R. Mediation-"Charting the right course for the new milleneum". INSAF, The Journal of the Malaysian Bar, (1999) XXXVIII No.3.

Darbyshire, P. (2001). Eddey on the English Legal System", 7th Edn, London: Sweet \& Maxwell, 2001 at pp. 107-108.

Davies, G.L. (2003). The Reality of Civil Justice Reform: Why We Must Abandon the Essential Elements of Our System' (2003) 12 Journal of Judicial Administration 155

EFS Was Replaced By E-Litigation EFS. [Online] Available: https://www.elitigation.sg/GetReady/ (Mac 15, 2015)

Hellriegel D., Jackson, S.E., \& Slocum, Jr., J.W. (2002). Management: A competency-based approach, South-western, 9th Edn, ThomasLearning, $\mathrm{p} 4$.

Johare, R., Hussin, N., \& Jamaludin, A. Management of Electronic Court Records: An Example from the TEAM Malaysia Case Studies. Proceeding paper presented at the InterPARES 3 International Symposium, 4-5 June 2009, Seoul, South Korea (Seoul: Sungkyunkwan University, 2009), p. 363-392. [Online] Available: http://www.interpares.org/display_file.cfm?doc=ip3_malaysia_ dissemination_cpr_johare_et-al_ip3-isym01_2009b.pdf (November 11, 2014).

Jackson, R. "Achieving a culture in case management" [2013] 1 LNS (A) xlix. para 2.1. Speech by Lord Justice Jackson, Fifth Lecture In The Implementation Programme, The Judicial Institute (22 November 2011). [Online] Available: http://www.judiciary.gov.uk/ Resources/JCO/Documents/Speeches/lcj-speech-vulnerable-witnesses-in-admin-of-criminal-justice-29092011.pdf (September 30, 2013).

Kotter, J.P., (2001). What leaders really do, Harvard Business Review, December, 3-12, p 4.

Lewis, P.S., Goodman, S.H. and Fanth, P.M. (2004). Management Challenges for Tomorrows leaders, 4th.Edn, Thomson Southwestern, $\mathrm{p} 24$.

MahWengKwai \& Associates, Malaysian Courts' Electronic Filing System. [Online] Available: http://www.mahwengkwai.com/wpcontent/uploads/2013/10/Electronic-Filing-System.pdf (Mac 18, 2015).

Mohiuddin, M.G. (2009). Islamic Management. (2nd. Ed). Agargaon, Dhaka: The University Grants Commission of Bangladesh.

Malayalam, G. (2005). Solicitors' Accounts: Theory and Practice. 1st.Edn.Kuala Lumpur: Gunasaiklaran Malayalam.

Mohamed Suffian (Tun), speech delivered at the Reference in honour of Tan Sri Dato' Wan Suleiman (2000). INSAF, Journal of the Malaysian Bar, XXIX, № 2, 85 at 87.

Newick, M., Hong Kong Court of First Instance case casts spotlight on new Practice Direction on 'e-discovery' between parties, (uploaded August 29, 2014). [Online] Available: http://www.cliffordchance.com/briefings/2014/08/ hong_kong_court_offirstin stance case cast.html (November 11, 2014).

Office of the Chief Registrar's Official Website. [Online]. Available: http://www.kehakiman.gov.my/e n/node/1534 (Mac 10, 2015).

Prest, W. \& Anleu, S.R. (2004). Litigation Past and Present. 1st.Edn. Australia: UNSW Press.

Saman, W.S.W. and Haider, A., Electronic Court Records Management: A Case Study, Journal of e-Government Studies and Best Practices. [Online] Available: http://www.ibimapublishing.com/journals/JEGSBP/jegsbp.html

Vol. 2012 (2012), Article ID 925115, DOl: 10.5171/2012.925115 (November 1, 2014).

Silver, C.S. (2013). Aiding the Plight of Self Represented Litigants: Admission to the

Magistrates' Court, Murdoch University Law Review (2013) 20 (1), p. 22. [Online] Available: https://mdulr.murdoch.edu.au/index.php/ mdulr/article/download/26/12 (November 10, 2014).

The Star, Nation Column, p. 10, 30 September 2014.

The Administration of Justice in Malaysia: A Memorandum from the Kuala Lumpur

Bar Committee, INSAF Journal of the Malaysian Bar (2001) XXX NO 2, June 2001, p. 39-63. 
Victorian Law Reform Commission - Civil Justice Review: Report, p. 219

World Bank. 2011. Court Backlog and Delay Reduction Programme: Malaysia Court Backlog and Reduction Program: A Progress Report, published by the World Bank in August 2011. [Online] Available: http://www.kehakiman.gov.my/index.php?q= en/node/ 615s (Mac 10, 2015).

Lord Woolf. (1999). Civil Litigation Reforms, INSAF, The Journal of the Malaysian Bar, (1999)XXXVIII No.3, p 69

Whetton, D.A. \& Cameron, K.S. (2002). Developing Management skills, 5th. Edn, Prentice Hall, p.3.

Zakiyy, N. (2010). Court Annexed Mediation in Resolving Disputes Relating to Family in Malaysia, Malaysian Journal of Syariah and Law, Vol. 2/2010: 135.

Zakaria, A. (2013). Speech by Tun Arifin Zakaria, Chief Justice of Malaysia, at the Opening of the Legal Year 2013 (Palace of Justice, Putrajaya, 12 Jan 2013). [Online] Available: http://www.malaysianbar.org.my/speeches/speech_by_tun_arifin_bin_zakaria_chief justice_of_malaysia_at_the_opening_of_the_legal_year_2013_palace_of justice_putrajaya_12_jan_2013.html (May 8, 2014). 